$\underline{\text { Avicenna Journal of Nursing and Midwifery Care - ISSN 2676-5748 }}$

\title{
Relationship Between Nurses' Emotional Intelligence with Clinical Decision-Making
}

\author{
Kobra Masoudi ${ }^{1}$, Azam Alavi $^{2 *}$ \\ 1. Master of Student, Health Services Management, School of Medical Sciences, Shahrekord Branch, Islamic Azad University, \\ Shahrekord, Iran \\ 2. Department of Nursing, School of Medical Sciences, Shahrekord Branch, Islamic Azad University, Shahrekord, Iran
}

\begin{tabular}{|c|c|}
\hline Article Info & ABSTRACT \\
\hline $\begin{array}{l}\text { Received: } 2019 / 10 / 25 \\
\text { Accepted: } 2020 / 09 / 25 \\
\text { Published Online: } 2020 / 10 / 11\end{array}$ & $\begin{array}{l}\text { Introduction: Higher levels of emotional intelligence have been associated with } \\
\text { better personal practice. Clinical decision-making, as the best solution for patients' } \\
\text { problems, is a crucial factor in clinical practice. The aim of this study was to determine } \\
\text { the relationship between nurses' emotional intelligence and clinical decision making. }\end{array}$ \\
\hline dof 10.30699 /ajnmc.29.1.14 & $\begin{array}{l}\text { Methods: This study is a correlation-descriptive study. A total of } 269 \text { nurses } \\
\text { working in the hospitals affiliated with Shahrekord University of Medical Sciences } \\
\text { were selected using a random stratified sampling in 2018. The data collection tools } \\
\text { were standard questionnaires of Shearing emotional intelligence and Laurie clinical } \\
\text { decision-making questionnaire. Statistical analysis was done using descriptive and } \\
\text { analytical statistics, by SPSS } 16 \text {. }\end{array}$ \\
\hline \multirow[t]{2}{*}{$\begin{array}{c}\text { Use your device to scan } \\
\text { and read the article online }\end{array}$} & $\begin{array}{l}\text { Results: The results of this study showed that there was a significant positive } \\
\text { correlation between emotional intelligence and clinical decision-making }(\mathrm{r}=0.273 \text {, } \\
P<0.001) \text {. Average total score of emotional intelligence in nurses was } 110.56 \text { that was } \\
\text { good ang higher than the mean of the questionnaire. Average total score of clinical } \\
\text { decision-making in nurses has been } 67.18 \text {. According to the questionnaire interpretation, } \\
\text { clinical decision-making of the units under study was intuitive. }\end{array}$ \\
\hline & $\begin{array}{l}\text { Conclusion: With regard to the relationship between emotional intelligence and } \\
\text { clinical decision-making, the importance of emotional intelligence in nurses is } \\
\text { determined. Therefore, hospital managers need to provide new ways to enhance nurses' } \\
\text { emotional intelligence, thereby enhancing the ability of clinical decision-making as the } \\
\text { vital point between theoretical and practical knowledge of the nursing profession. }\end{array}$ \\
\hline
\end{tabular}

Keywords: Emotional intelligence, Clinical decision-making, Nurses

How to Cite This Article:

Masoudi K, Alavi A. Relationship Between Nurses' Emotional Intelligence with Clinical DecisionMaking. Avicenna J Nurs Midwifery Care. 2020; 29 (1) :14-22 


\section{ارتباط هوش هيجانى يرستاران با تصميمَّيرى بالينى \\ كبرى مسعودى'، اعظم علوى ז"}

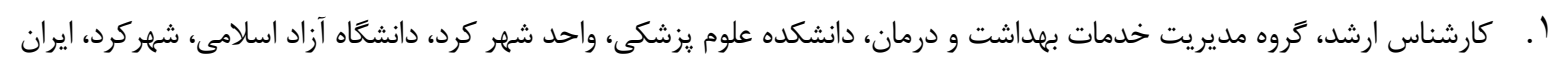

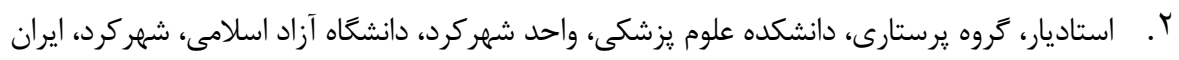

\begin{tabular}{|c|c|}
\hline جكيده & اطلاعات مقاله \\
\hline 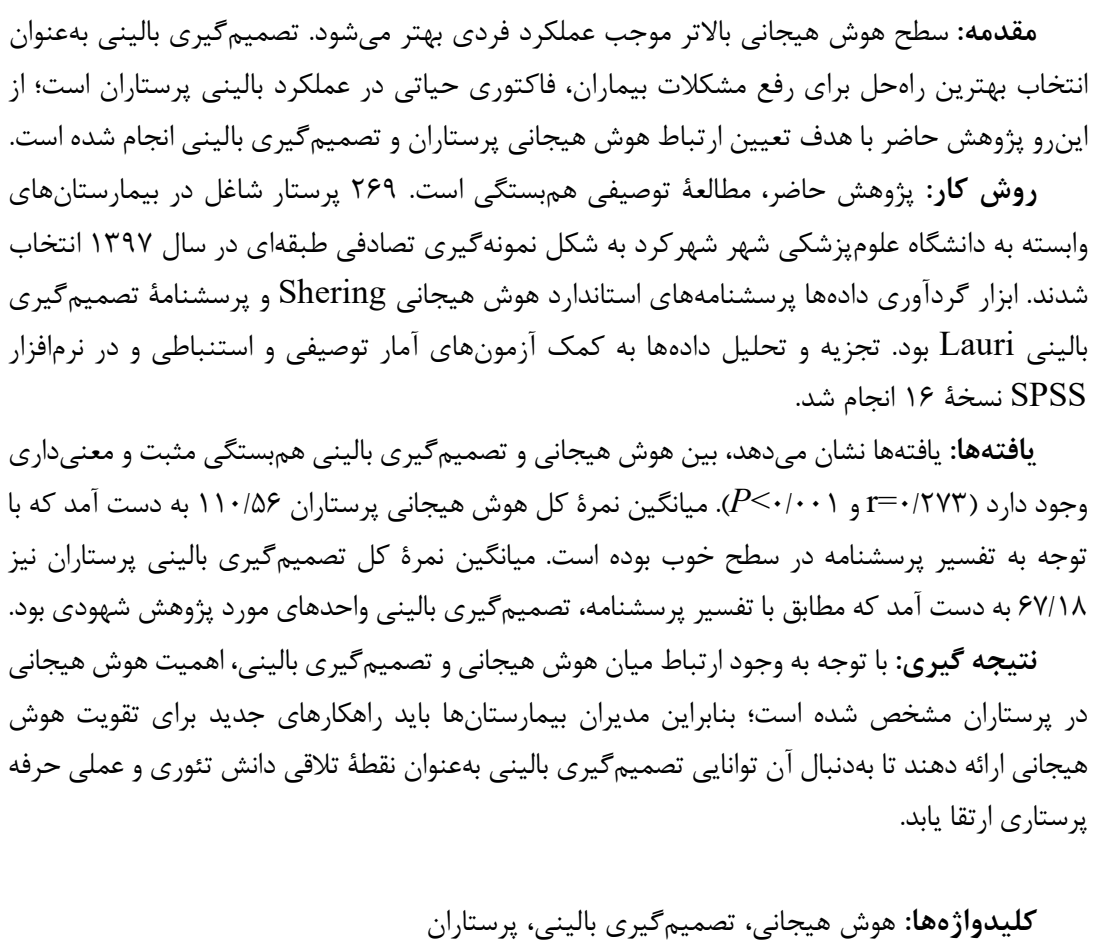 & 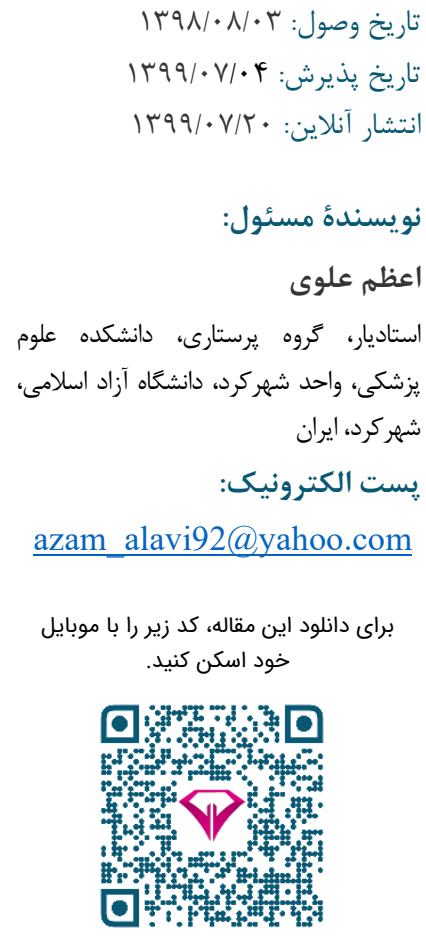 \\
\hline
\end{tabular}

بيشترى در مديريت مشكلات هيجانى دارند. هوش هيجانى نوعى از هوش شناختى است كه شامل يك دسته از توانايىها،

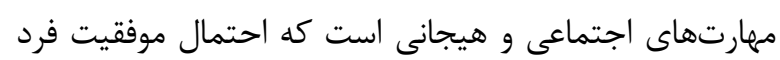

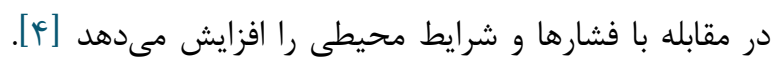
هوش هيجانى توانايى فرد براى حل مشكلات و تنظيم رفتارها بلهوسيله شناسايى، تشخيص و استفاده از اطلاعات هيجانى خود با ديخران است [ه]]. همجنين مجموعهاى از توانايىهاى تهيص شناختى و هيجانى بههمرييوسته است كه به فرد كمك مى كند با دريافت، ارزيابى و بيان دقيق هيجانها، از احساسهانهايى كه بهونيته

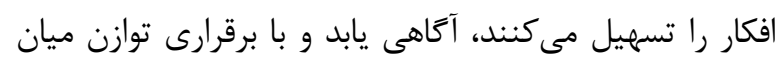

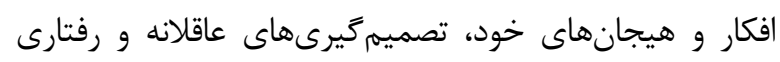

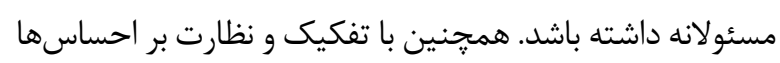

هوش به رفتار انطباقى فرد اشاره مى كند كه معمولاً داراى عنصرى از حل مسئله است و بلهوسيلة فرايندها و عمليات شناختى هدايت مىشود [1]]. هوش به انواع مختلفى مانند

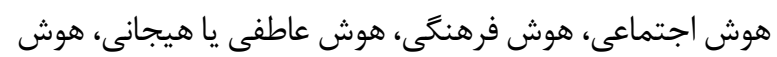

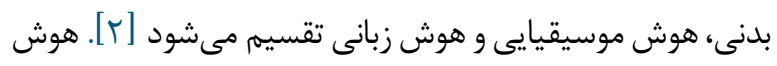

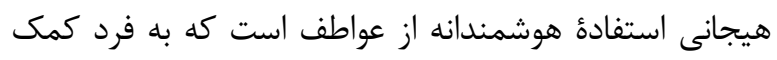
مى كند با استفاده آكاهانه از عواطف، توانايى تمايز عواطف و و

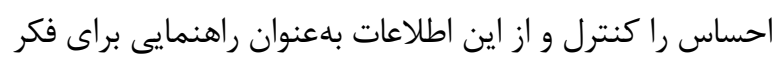

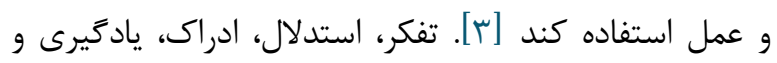
حافظهٔ فرد تحت تأثير حالات هيجانى هستند، اين امر نشانكر نياز به درك يويايى هيجانات براى درك رفتار انسان است.

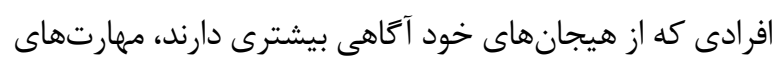


بخش اساسى كار حرفهاى يرستاران است كه مىتوان آن را

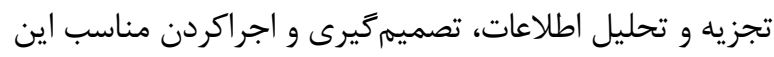

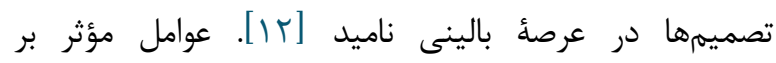

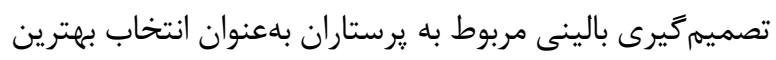

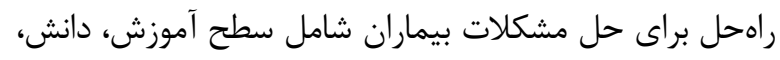

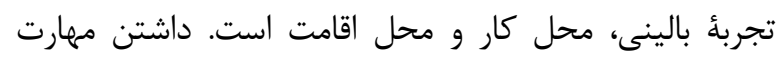

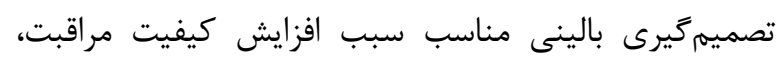

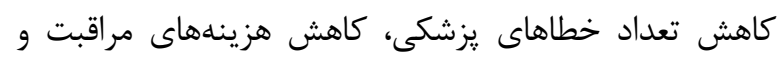

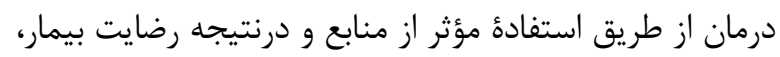

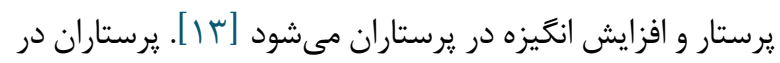

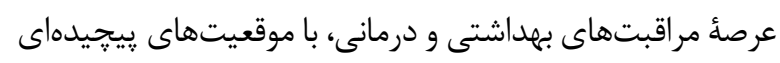

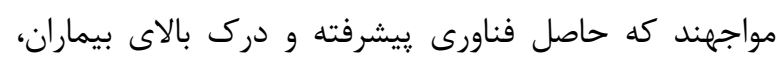

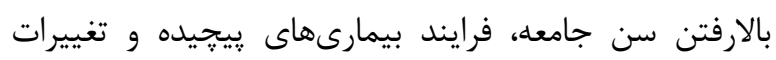

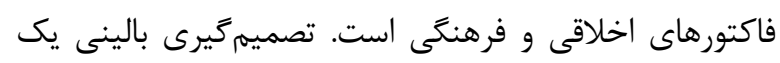

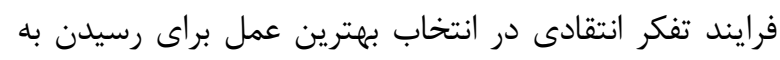

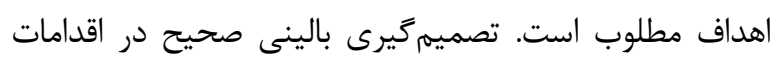
يرستارى موجب طرحريزى منطقى مراقبتى با حداكثر احتمال

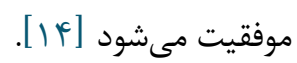
يرستار ان بهعنوان حافظان سلامت جامعه نقشى كليدى در

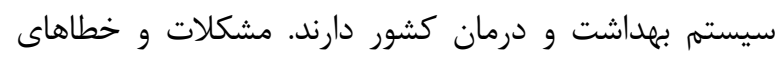

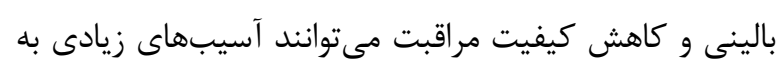

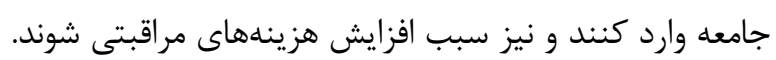

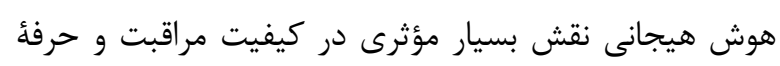

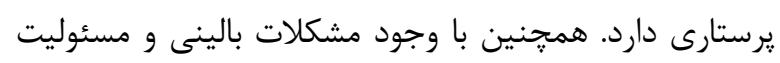

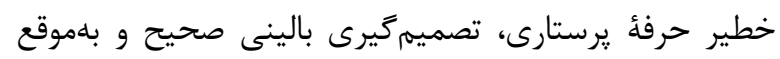

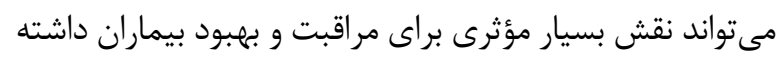

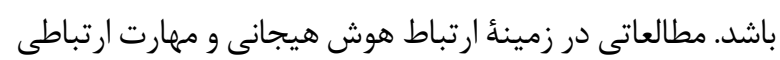

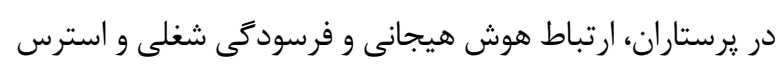

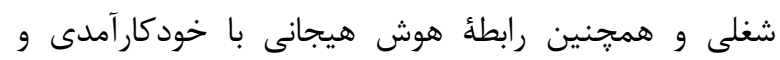

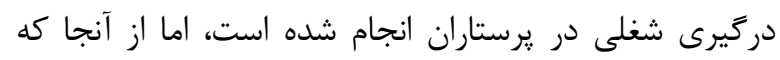

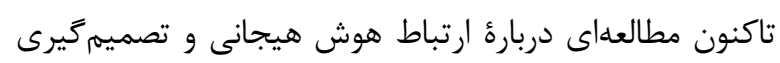

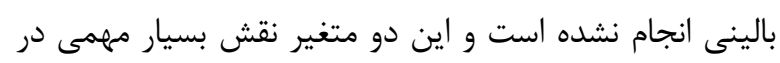

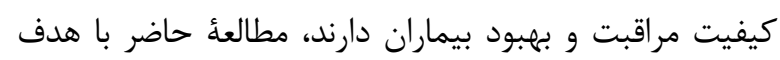
تعيين ارتباط هوش هيجانى و تصميمَّيرى بالينى يرستاران

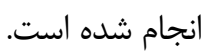

و هيجانهاى خود و ديخران از دانش عاطفى براى هدايت تفكر، ارتباط خود و ديغران استفاده كند [ع] هون.

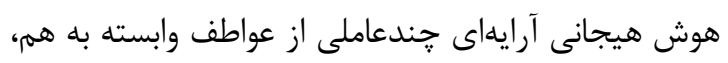

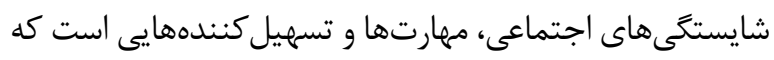

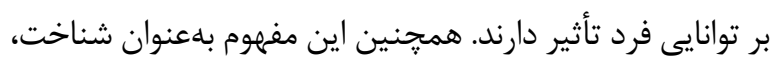

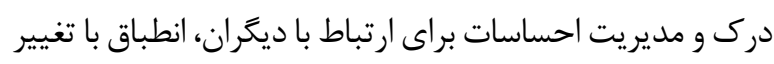

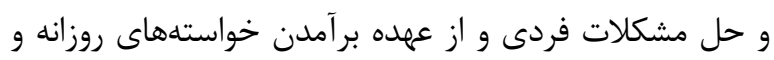

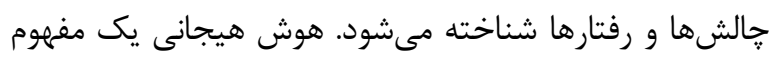

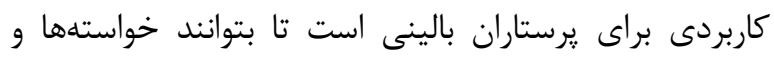

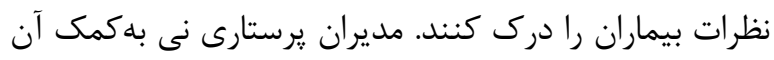

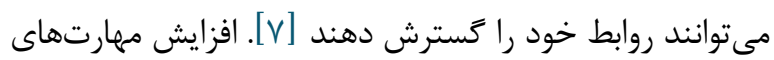

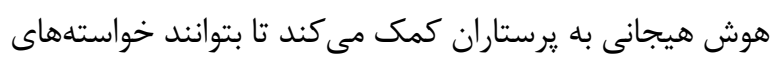

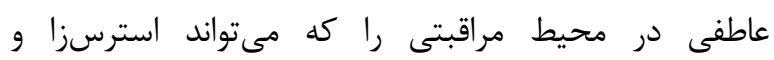

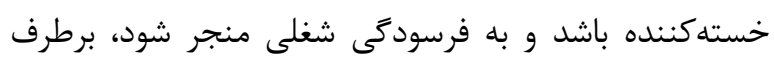

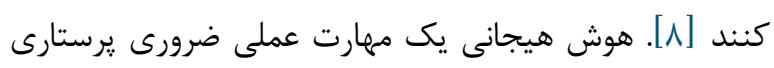

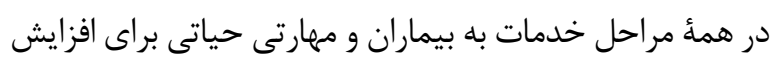

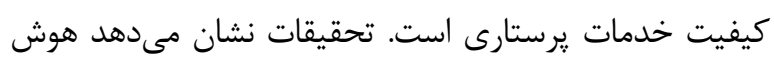

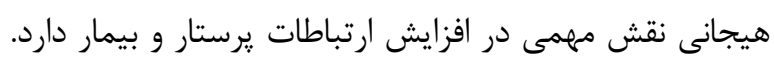

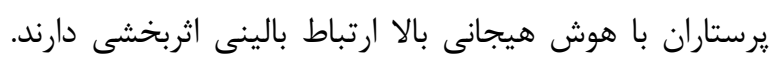

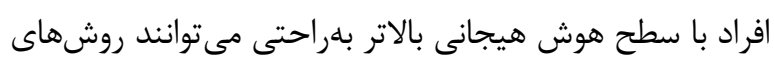

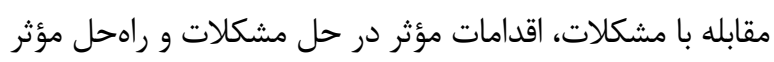

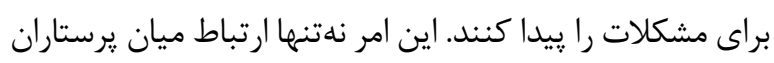

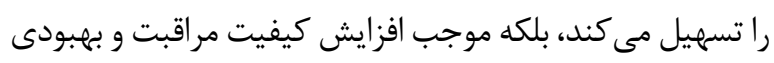

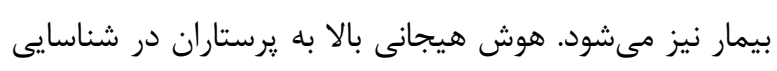

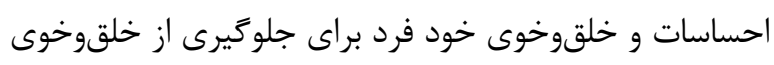

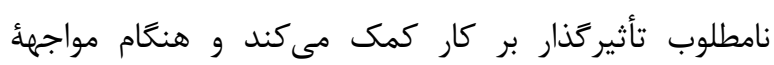

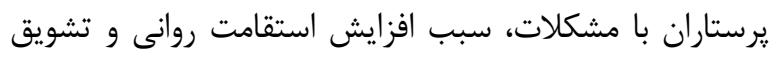

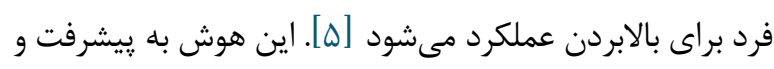

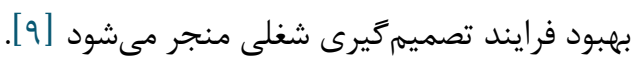

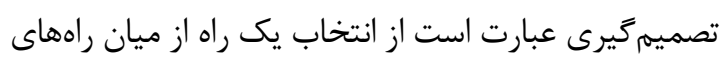

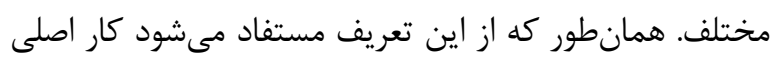
تصميم گيرنده كشف راههاى ممكن و نتايج ناشى از آنها آنها وانتخاب

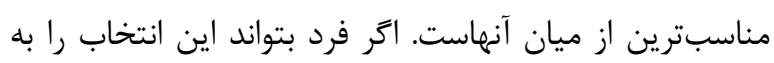

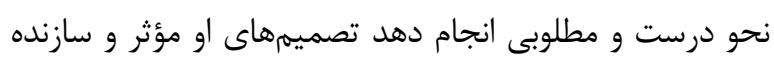

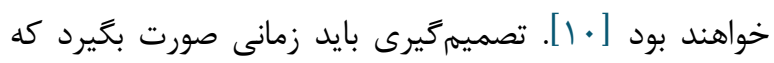

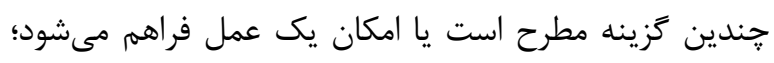

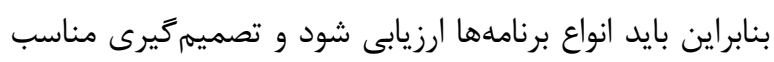

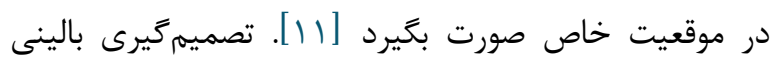


و بيان كنندة سطح دوم تصميم گيرى يعنى تحليلى شهودى و VA

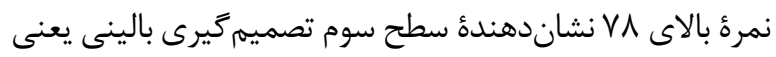
شهودى تفسيرى است. پايايى اين :رسشنامه در مطالعأ Karimi Naghandar

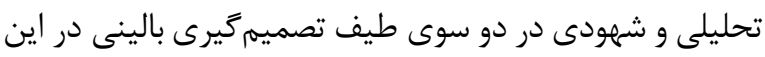
ابزار هستند. تصميمَيرى شهودى، ارتباط برقراركردن ميان

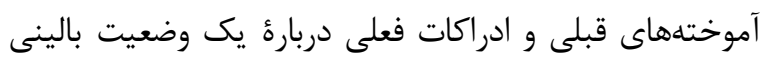

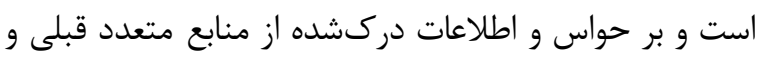
فعلى تكيه دارد؛ درحالى كه فرايند تحليلى يكى روش خطى اطنى براى دراي

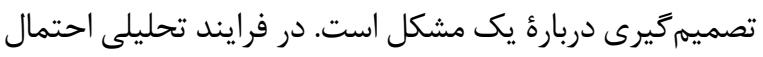

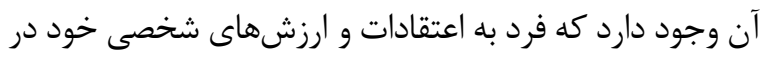

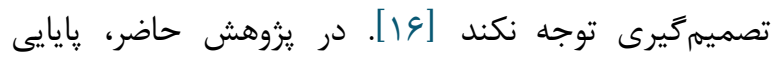

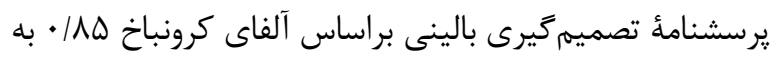
دست آمد كه مناسب تشخيص داده شد. يس از كسب مجوز و معرفىنامه از رياست محترم دانشخاه

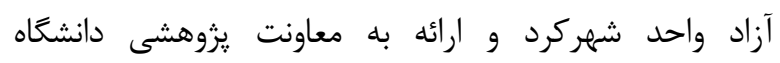

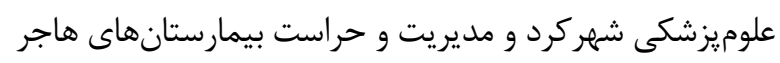
و كاشانى شهر شهركرد و كسب اجازه از ايشان ابتدا توضيحات

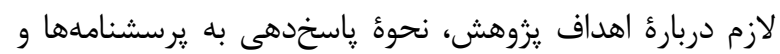

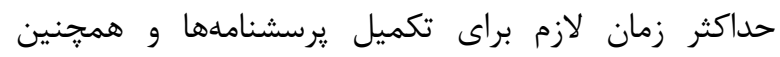

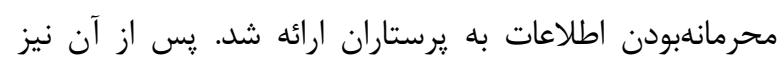

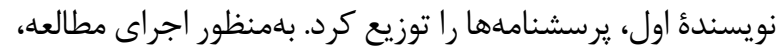

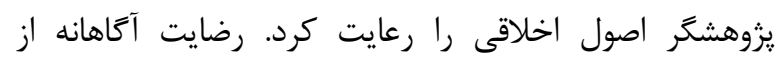

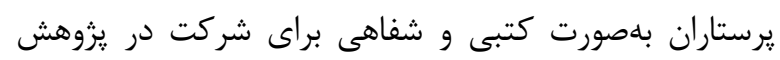

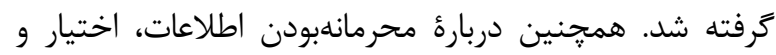

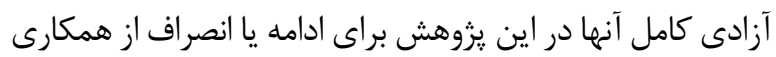

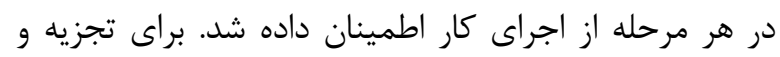

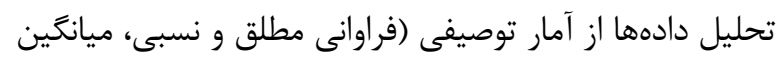

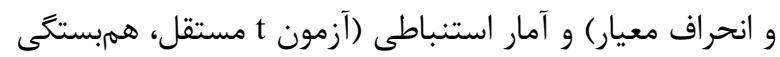

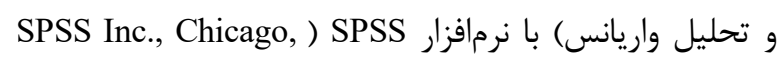
(Ill., USA

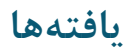

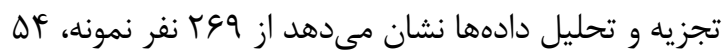

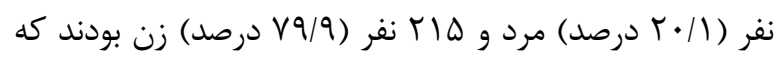

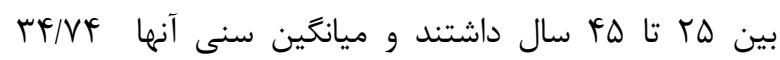

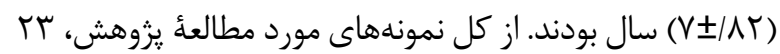

روش كار

يزوهش حاضر مطالعؤ توصيفى - همبستخى است كه در سال

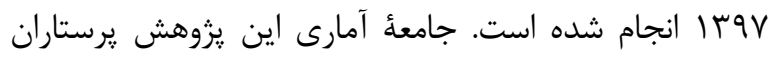

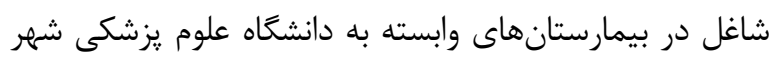

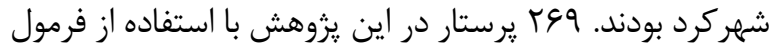

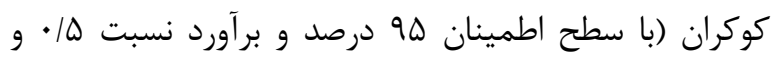

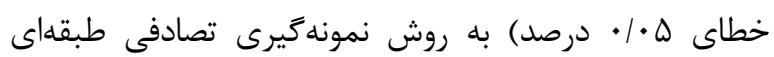

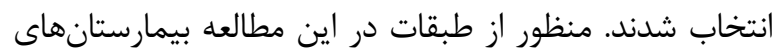

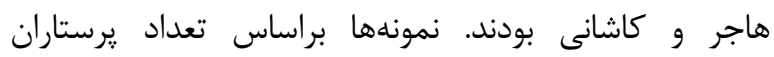

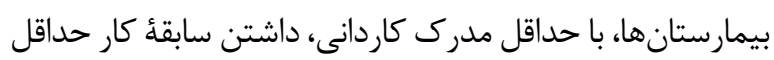
يك سال با انواع استخدام طرحى، قراردادى، شركتى، يِيمانى و رسمى بهصورت تصادفى مطابق معيارهاى ورود انتخاب شدند.

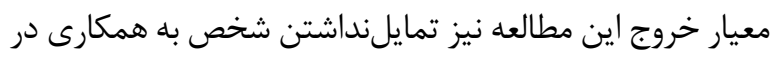

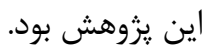

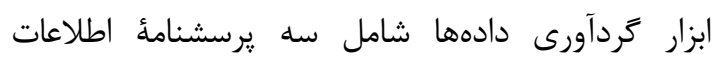

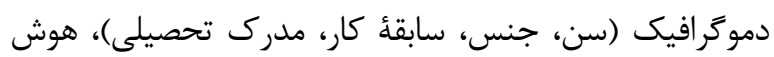

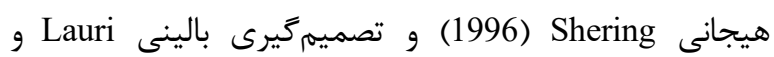
همكاران (2001) بود. يرسشنامٔ هوش هيجانى داراى سٓ عبارت

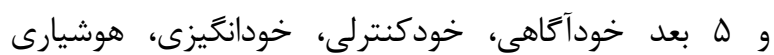

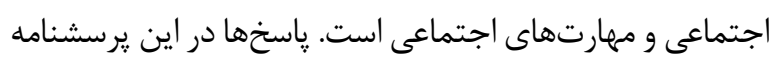
براساس مقياس ليكرت ينجزينهاى (هميشه، اغلب اوقات،

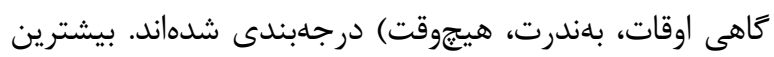

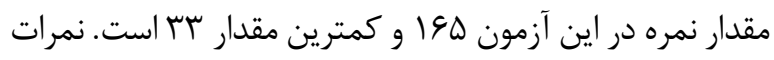
וTD-FD

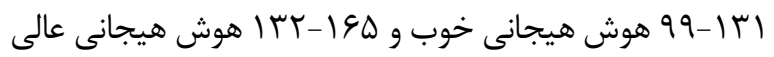

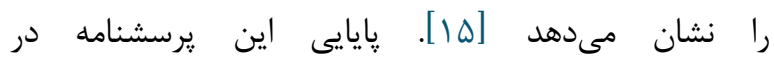

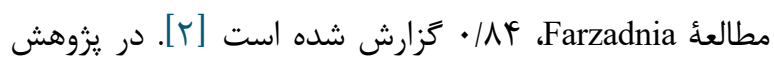
حاضر، پايايى يرسشنامة هوش هيجانى Shering براساس آلفاى كرونباخ AVV/ • مناسب تشخيص داده شد.

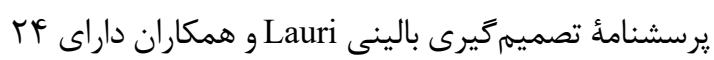

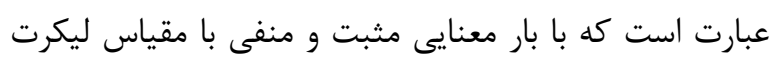

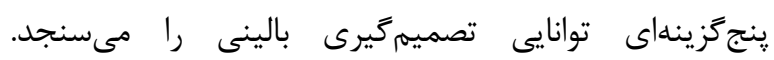

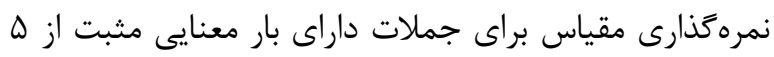

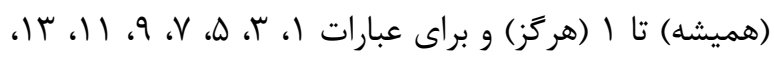

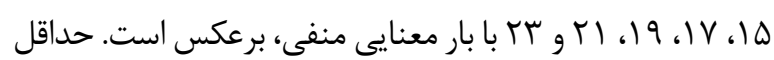

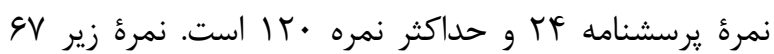

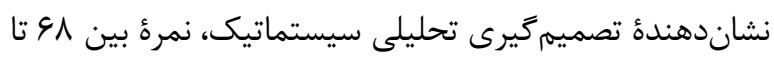




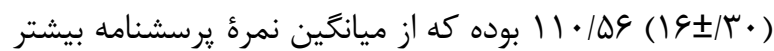
است. براساس تفسير يرسشنامه، سطح هوش هيجانى يرستاران خوب بوده است. همجنين نتايج نشان مى دهد در ميان ابعاد

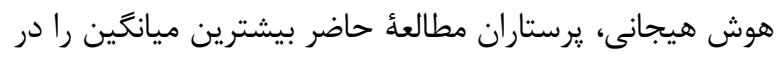
بعد خودآكاهى كسب كردهاند؛ يعنى (

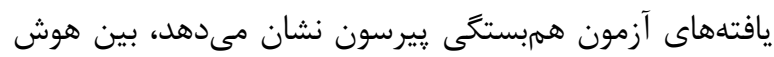

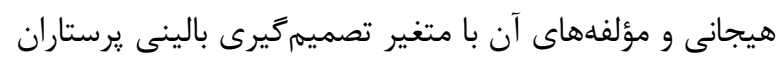
شركت كننده در مطالعه، رابطهاى مستقيم و معنى دار وجود دارئ دارد

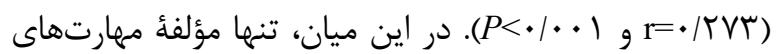

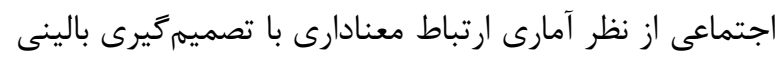

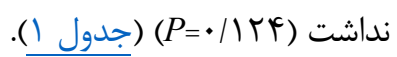

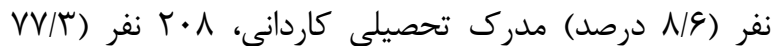

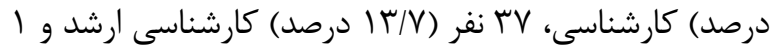

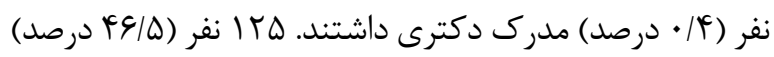

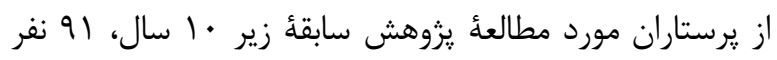

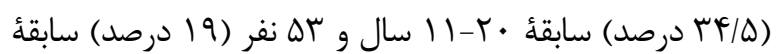
بيش از • · ب سال داشتند.

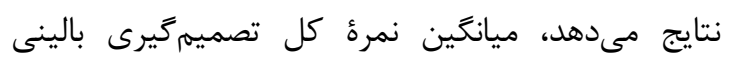

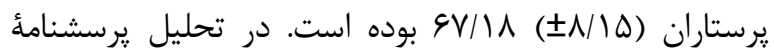

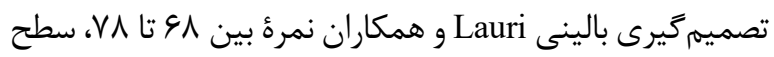
دوم تصميمَيرى يعنى تحليلى شهودى است. همجنينين

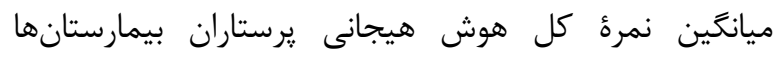

جدول ا. ارتباط ميانغين نمرهٔ هوش هيجانى و مؤلفهاى آن با تصميمَيرى بالينى ثبرستاران

\begin{tabular}{|c|c|c|c|}
\hline " همبستگى با متغير تصميم كيرى & انحراف معيار & ميانَين & مؤلفه هاى هوش هيجانى \\
\hline $\begin{array}{l}\mathrm{r}=\cdot / r r r \\
P=\cdot / \cdot \bullet \Delta\end{array}$ & $F / \Delta \Delta$ & זr/Tr & خودانگيزى \\
\hline 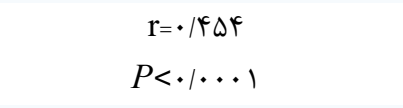 & $r / V I$ & TE/TI & خودآكاهى \\
\hline $\begin{array}{c}\mathrm{r}=\cdot|r T| \\
P<\cdot \mid \cdots \cdot 1\end{array}$ & r/fG & $r \cdot / I V$ & خود كنترلى \\
\hline $\begin{array}{l}\mathrm{R}=\cdot / / V r \\
P=\cdot / \cdot \bullet\end{array}$ & $F / I T$ & Tr/AG & هوشيارى اجتماعى \\
\hline $\begin{array}{l}\mathrm{r}=\cdot / \cdot 9 \Delta \\
P=\cdot / 1 T r\end{array}$ & $F / T V$ & 11 & مهارتهاى اجتماعى \\
\hline $\begin{array}{l}\mathrm{r}=\cdot / \mathrm{Vr} \\
P=\cdot / \cdot \cdot 1\end{array}$ & $19 / \pi$. & $11 \cdot 1 \Delta 9$ & نمرة كلى هوش هيجانى \\
\hline
\end{tabular}

ميانگين نمره هوش هيجانى تفاوت معنى هارى نداشت

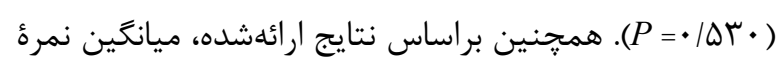
تصميمى

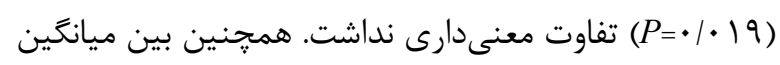

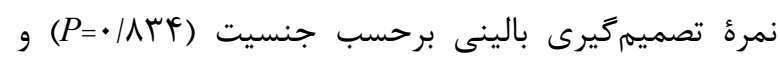

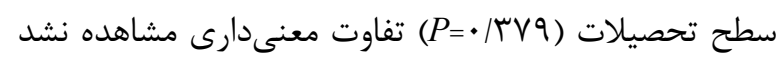
(جدول)
در مطالعهُ حاضر، براى تعيين تفاوت ميانگين هوش هيجانى و تصميم گيرى بالينى برحسب متغيرهاى سن، سابقه كار، تحصيلات و جنسيت، از آزمونهاى تحليل واريانس تصني يكطرفه (ANOVA) و t مستقل استفاده شد. نتايج نشان

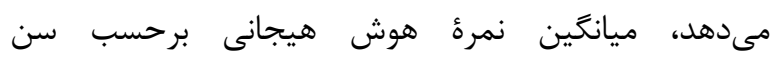

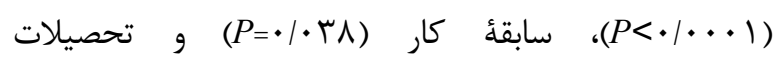
(•) (P=اوت معنى دارى دارد، اما برحسب جنسيت، 
جدول r. ارتباط هوش هيجانى و تصميمَيرى بالينى ير ستاران با برخى متغير هاى دموكرافيك

\begin{tabular}{|c|c|c|c|c|c|}
\hline آزمون آمارى & تصميم تيرى بالينى & آزمون آمارى & ميانخين 土 (انحراف هيجانى معيار) & تروه & متغير \\
\hline \multirow{4}{*}{$\begin{array}{c}\text { Anova } \\
\mathrm{df}=r \\
P=\bullet / . \bullet \varnothing\end{array}$} & $94 / 10 \pm(1 . / 99)$ & \multirow{4}{*}{$\begin{array}{c}\text { Anova } \\
\mathrm{df}=r \\
P<\cdot / \ldots)\end{array}$} & $q V / \cdot \Delta \pm(r T / q))$ & كمتر از هr سال & \multirow{4}{*}{ سن } \\
\hline & $9 \Delta / \wedge) \pm(1 \cdot / \& \mathrm{~V})$ & & $1 \cdot N / 1 Q \pm(r \backslash / r q)$ & عץ تا هז سال & \\
\hline & GN/GT $\pm(\mid D / \cdot \Lambda)$ & & $\| \Delta / q T \pm(T \Delta / \Lambda T)$ & عץ تا هـ سال & \\
\hline & $\pm 1 \cdot / V^{\mathbb{E}}\left(1 \varepsilon / \mathbb{F}^{\mathbb{E}}\right)$ & & 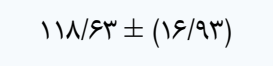 & بيشتر از هأ سال & \\
\hline \multirow{2}{*}{$\begin{array}{l}\text { T-test } \\
\mathrm{df}=r g \mathrm{~V} \\
P=\cdot / \text { ^rץ }\end{array}$} & \multirow[b]{2}{*}{$S V / T F \pm(\Lambda / T))$} & \multirow{2}{*}{$\begin{array}{l}\text { T-test } \\
\mathrm{df}=r g r \\
P=\cdot / \Delta r .\end{array}$} & $111 / \wedge 1 \pm(\mid f / Q \Lambda)$ & 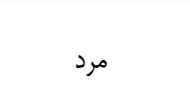 & \multirow{2}{*}{ جنسيت } \\
\hline & & & $11 \cdot / r \Delta \pm\left(19 / 9 T^{4}\right)$ & زن & \\
\hline \multirow{4}{*}{$\begin{array}{l}\text { Anova } \\
\mathrm{df}=\mathrm{r} \\
P=/ \text { rvq }\end{array}$} & $q r / q) \pm(\mid r / q \varepsilon)$ & \multirow{4}{*}{$\begin{array}{c}\text { Anova } \\
\mathrm{df}=r \\
P=\cdot / \cdot 19\end{array}$} & $1 \cdot N / \mu^{\prime} \varepsilon \pm(1 \cdot / \pi)$ & كاردانى & \multirow{4}{*}{ سطح تحصيلات } \\
\hline & $8 \mathrm{~V} / \cdot \wedge \pm(\Lambda / \wedge)$ & & $\| r / \Delta T \pm(|\xi /| \varepsilon)$ & كارشناسى & \\
\hline & $q q / r) \pm(r / / r)$ & & $\mid r \cdot / r t \pm(q / q)$ & كارشناسى ارشد & \\
\hline & $9 \Lambda \cdot \pm$ & & (ז. & دكترى & \\
\hline \multirow{3}{*}{$\begin{array}{c}\begin{array}{c}\text { Anova } \\
\mathrm{df}=r\end{array} \\
P=\cdot / \cdot 19\end{array}$} & $\varepsilon \Delta / K^{\prime} E \pm(1 \cdot / \Lambda F)$ & \multirow{3}{*}{$\begin{array}{l}\text { Anova } \\
\mathrm{df}=r \\
P=. / .\end{array}$} & $1 \cdot \Gamma / \Delta) \pm(T r / Q \Delta)$ & كمتر از • ا سال & \multirow{3}{*}{ سابقأ كار } \\
\hline & $99 / 91 \pm(11 / 94)$ & & $\| I F / \cdot r \pm(r r / r V)$ & بين •r-I| سال & \\
\hline & $V / r^{\prime} \pm(M / r)$ & & $\| \Delta / V \Delta \pm(\Gamma \digamma / \cdot 1)$ & بالاى .r.r سال & \\
\hline
\end{tabular}

عمل زياد و در مراقبت قبل و بعد از عمل كم ارزيابى كردهاند

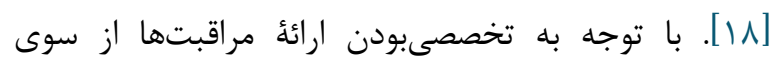

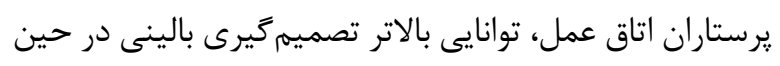

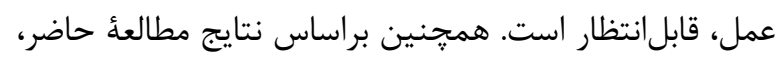

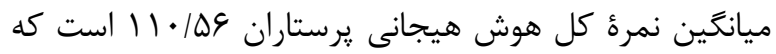

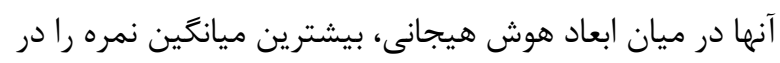

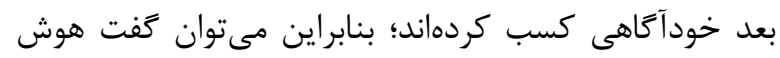

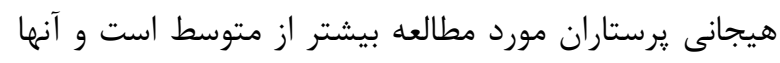

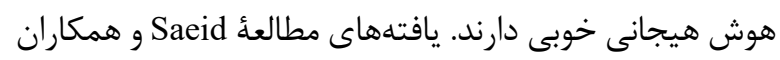

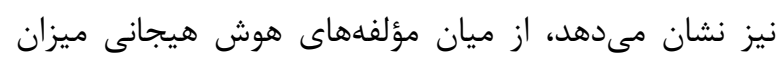

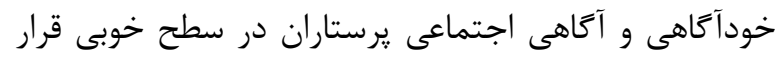
دارد [19]. يرستاران اين مطالعات همسو با مطالعئ اخير،

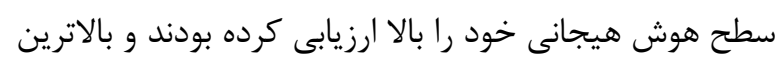

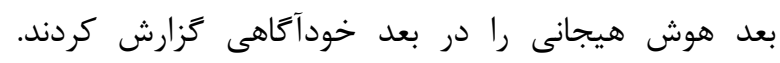

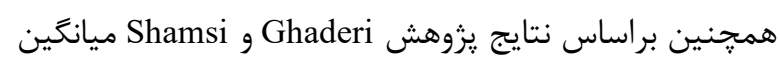

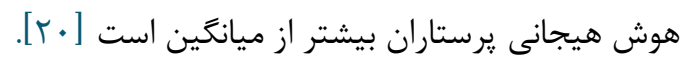

\section{بحث}

نتايج تجزيه و تحليل يافتهها نشان مى دهد، ميانكين نمرة

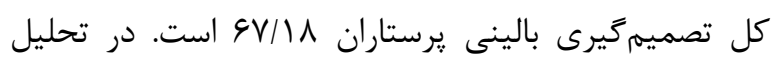

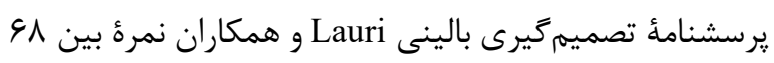

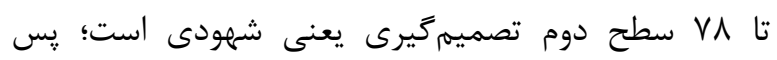

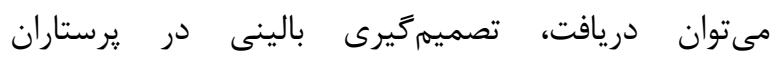

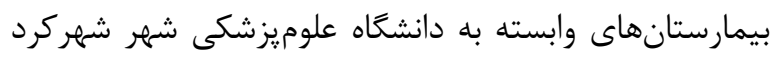

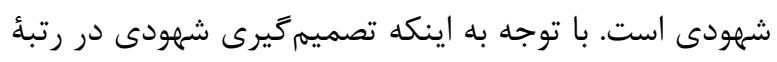

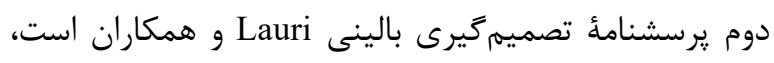

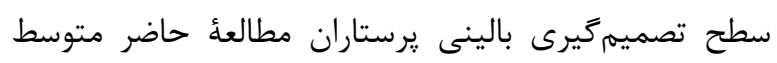

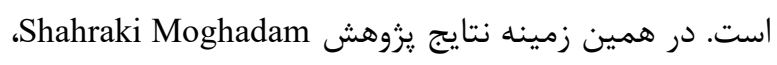
و و نشان مى دهد، مشار كت برستاران در هر سه مرحلة تصميم گيرى بالينى شامل شناخت مشكل، ارائٔ

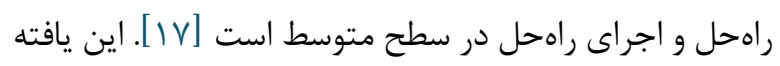
با نتايج مطالعه حاضر همسوست. همرجنين براساس دراس نتايج

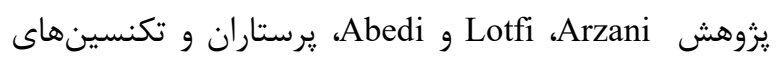

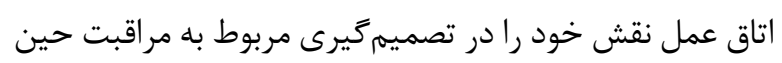




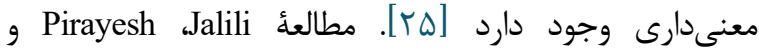
نشان مىدهد، بين متغيرهاى اصلى تحقيق (هوش هيجانى و تصميم گيرى سرمايهذاران) رابطهاى مستقيم

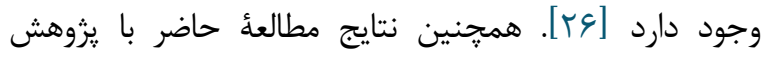

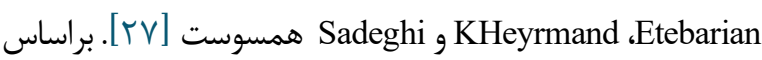
نتايج اين مطالعات، مفهوم هوش هيجانى با انواع تصميم كيرىهاى

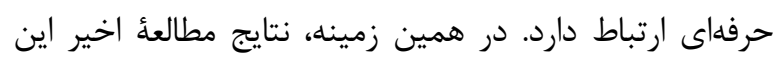
ارتباط را بين هوش هيجانى و تصميمَيرى حرفهاى يرستاران در

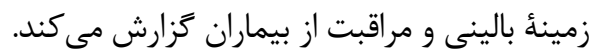

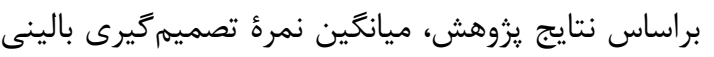

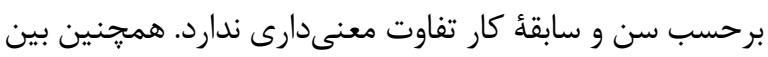

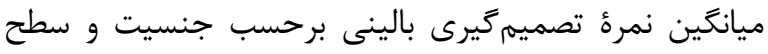

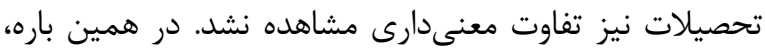
Lak Dizaji سن و جنسيت ارتباط آمارى معنى دارى دارد، اما اين رابطه بارئا

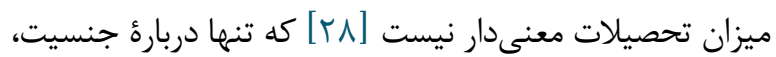

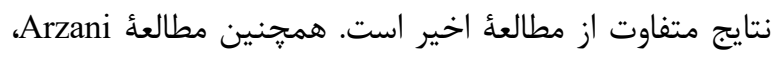
Abedi و Lotfi

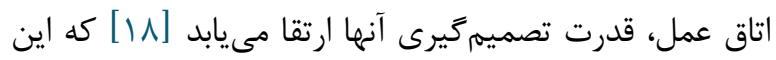

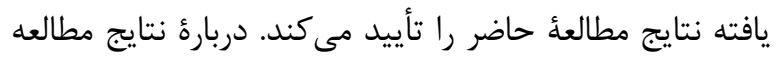

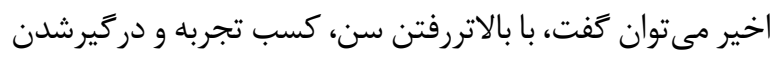

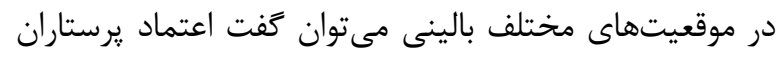

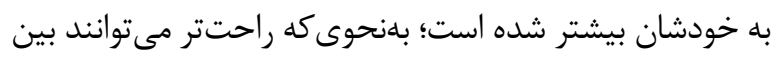

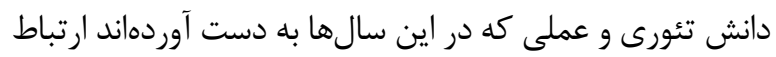

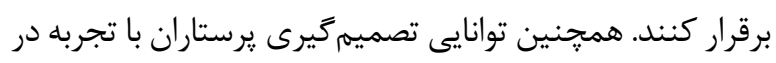

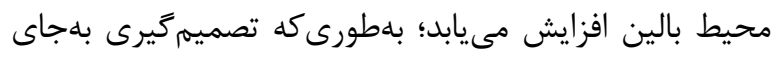

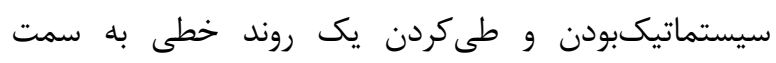
تصميمَّيرى شهودى و شهودى تفسيرى مىرود. همجنين ميانكَين نمرءٔ هوش هيجانى برحسب سن، سابقئ

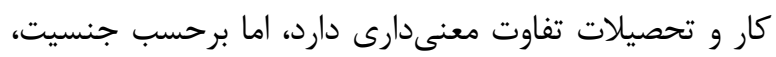

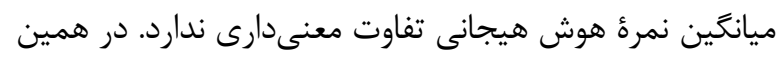

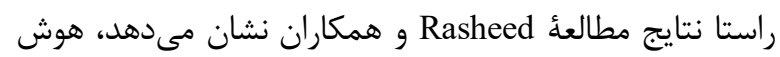

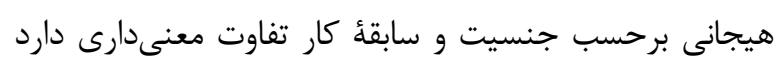

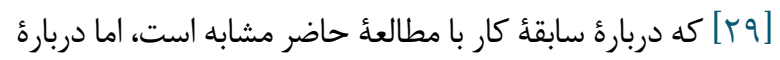

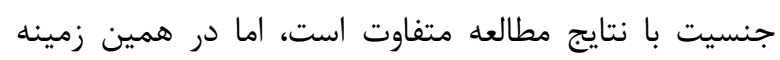

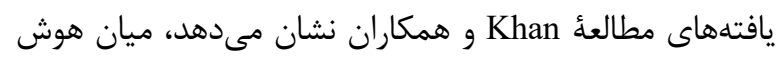

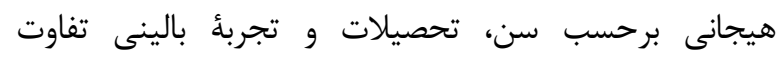
معنى دارى وجود ندارد، اما برحسب جنسي تحيلات وحيت تفاوت معنى دارى بالينى تفاوت
يافتههاى يزوهش نشان مىدهد، ميان هوش هيجانى و

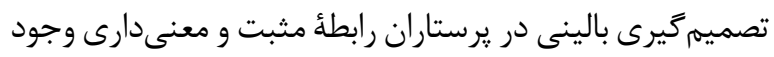

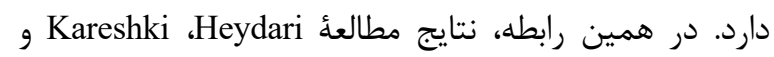

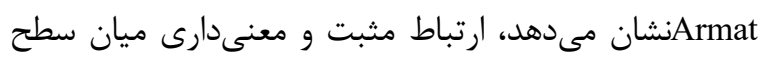

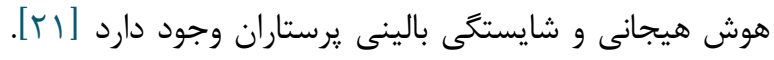

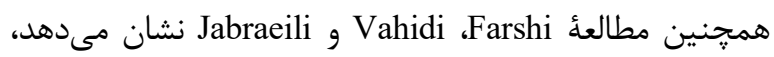
ارتباط مثبت و معنى دارى بين هوش هيجانى و شايستگى بالينى مانى

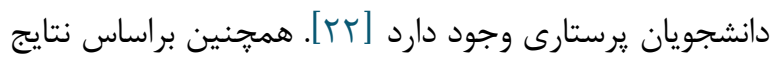

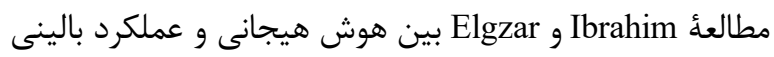
دانشجويان يرستارى در مدت كار آموزى مامايى و مراقبت إن از زئنان

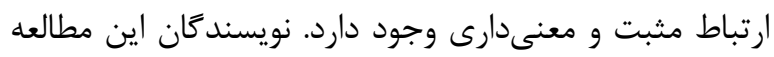

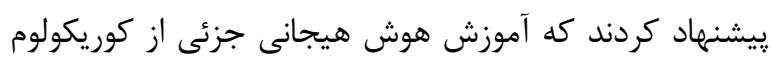

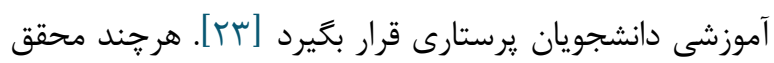

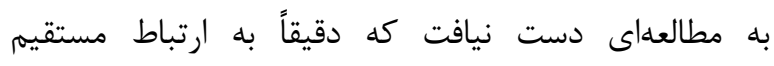

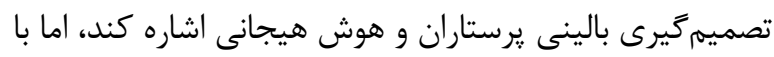

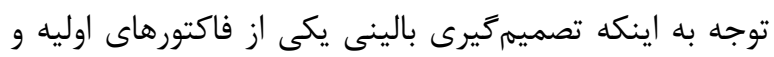

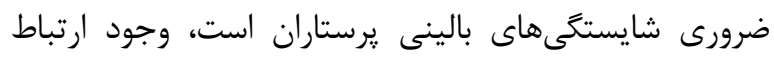

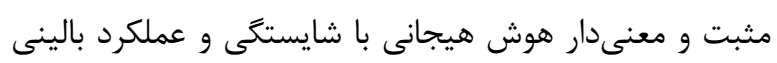

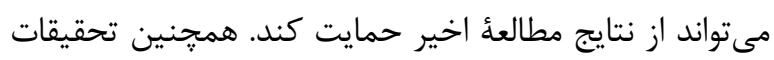

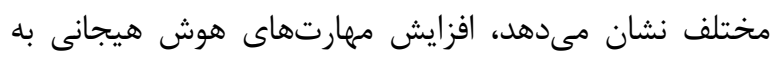

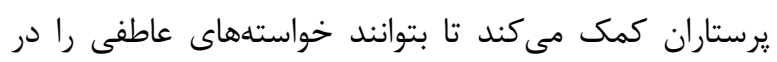

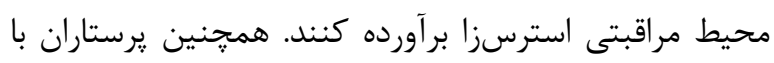

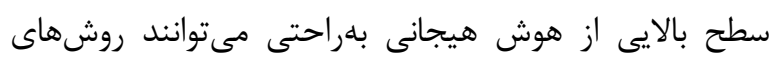

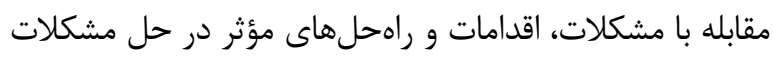

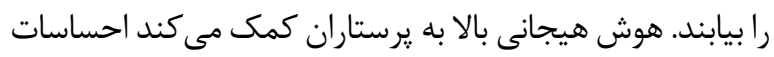

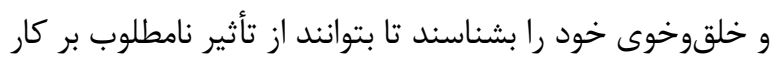

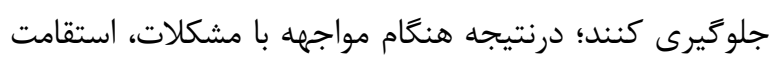

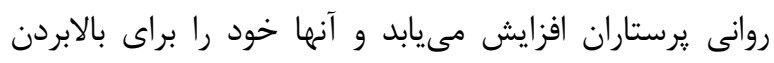

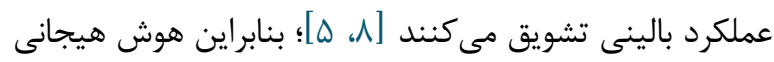

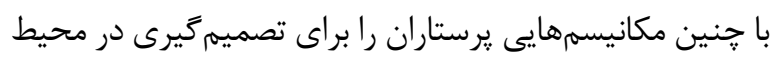

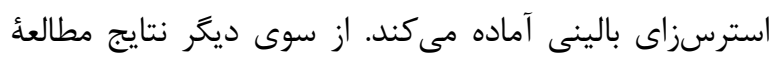

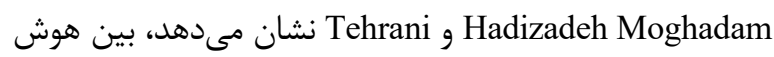
عاطفى و سبكهاى تصميمَيرى عقلايى و اجتنابى مديران،

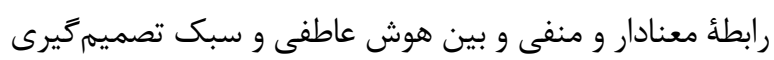

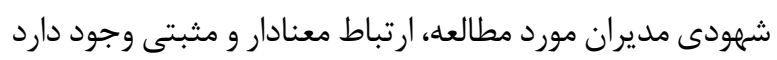

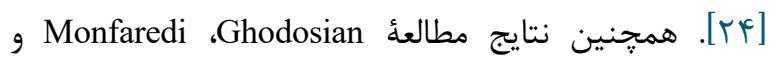
Asgarzadeh

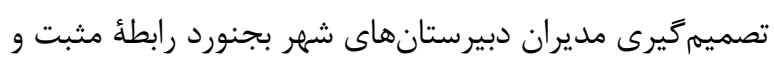


داشته باشند و راهكارهاى جديدى براى تقويت هوش هيجانى ارائه كنند تا توانايى تصميمَيرى بالينى يرستاران بهعنوان

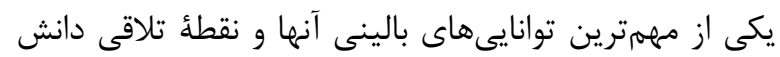

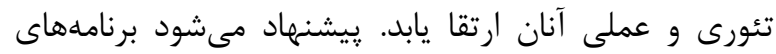
خاصى مانند برگزارى سمينارها براى تقويت هوش هيجانى با استفاده از استادان روانشناسى متخصص در در اين حيطه براى

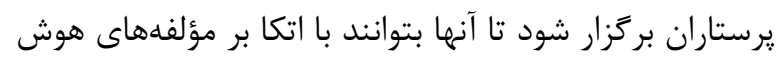

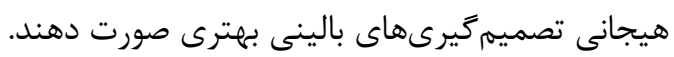

\section{سياسخزارى}

بدينوسيله از معاونت محترم تحقيقات و فناورى دانشعاه

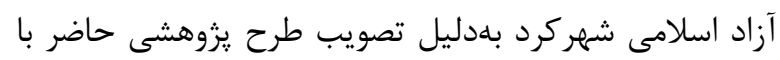

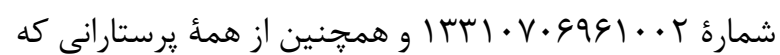
وقت كرانمايه و تجارب ارزشمند خود را در اختيار ما قرار دادند، صميمانه تشكر و قدردانى مى كنيم.

$$
\text { تعارض در منافع }
$$

بين نويسندگان هيجگ گونه تعارضى در منافع وجود ندارد

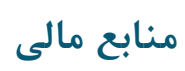

منابع مالى اين مطالعه توسط نويسندكان تامين شده است.

\section{References}

1. Seyf A. Educational psychology: learning and teaching psychology. Tehran: Agah; 2018. (In Persian)

2. Farzadnia F. The Impact of Emotional Intelligence on the Conflict Management Styles in Tehran's Milad Hospital Administrators. J Ilam University of Medical Sciences. 2012; 20(2): 53-61. (In Persian)

3. 3. Rostami M, Movaghari MR, Taghavi T, Mehran A. The relationship between Emotional Intelligence and Styles of coping with Stress in Nurses of the Hospital, Kermanshah University of medical sciences. J Nurs. 2016; 11(1):51-61. (In Persian)

4. Barkhordari M, Rostam beigi P, Gasemnegad M. Measurement of the Rate of Emotional Intelligence of Nursing students. J Nurs. 2015; 10(4):12-19. (In Persian)

5. Zhu B, Chen CR, Shi ZY, Liang HX, Liu B. Mediating effect of self-efficacy in relationship between emotional intelligence and clinical communication competency of nurses. International Journal of
مشاهده مىشود [ [ץ]. در همين زمينه، بلهنبال افزايش سن و سابقه كارى، خودشناسى و ديخرشناسى افزايش مىيابد و

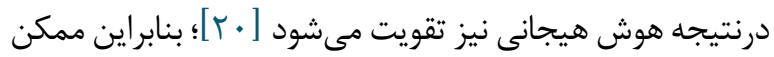
است يرستارانى با سابقهُ كارى و تجربئ بيشتر و با تحصيلات بالاتر با توجه به شناخت عميقتر از خود و احساسات خود ميانگين نمره هوش هيجانى بيشترى را گزارش كنند؛ البته

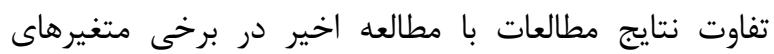
دموگر افيك ذكرشده با توجه به تفاوت عوامل زمينهاى مانند ارائه مراقبت يرستارى تنها در يك بخش تخصصى، فرهنگ و كشور

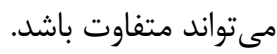

$$
\text { نتيجه گيرى }
$$

براساس نتايج مطالعهُ حاضر، تصميمزيرى بالينى در يرستاران تصميمزيرى شهودى است. ميانخين نمره هوش برى هيجانى يرستاران نيز بيشتر از ميانگين نمره يرسشنامه است. همجنين بين هوش هيجانى و تصميمثيرى بالينى در

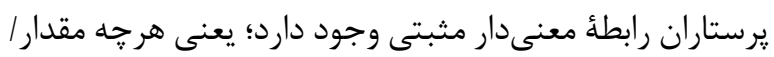
اندازه هوش هيجانى بيشتر شود، توانايى تصميمَيرى بالينى افزايش مىيابد. با توجه به نتايج مطالعه، ضرورت و اهميت

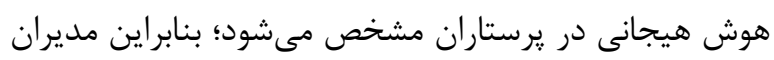
بيمارستانها بايد توجه زيادى به هوش هيجانى يرستاران

Nursing Sciences. 2016; [DOI:10.1016/j.ijnss.2016.04.003]

6. Shakeri nia E. The relationship between emotional intelligence and emergency department nurses selfefficacy beliefs with the consent of the patients of the treatment process. J Hospital. 2010; 9(3,4). (In Persian)

7. Tagoe T, Quarshie EN. The relationship between emotional intelligence and job satisfaction among nurses in Accra. Nurs Open. 2017;4(2):84-9. [DOI:10.1002/nop2.70] [PMID] [PMCID]

8. Başoğul C, Özgür G. Role of emotional intelligence in conflict management strategies of nurses. Asian nursing research. 2016; 10(3):228-33. [DOI:10.1016/j.anr.2016.07.002] [PMID]

9. Mirhashemi M, Sharifi H, Sabeti SH. The relationship between nurses 'jobs conflict with emotional intelligence. J Andisheh va Raftar. 2009; 3(9). (In Persian) 


$$
\text { r r ارتباط هوش هيجانى يرستاران با تصميمَيرى بالينى }
$$

10. Masoodi asl I. Nursing management. jameenegar. 6th; 2018. (In Persian)

11. Hagbaghery MA, Salsali M, Ahmadi F. The factors facilitating and inhibiting effective clinical decisionmaking in nursing: a qualitative study. BMC Nurs. 2004;3(1):1-1. [PMID] [PMCID]

[DOI:10.1186/1472-6955-3-2]

12. White AH. Clinical decision making among fourthyear nursing students: An interpretive study. Journal of Nursing Education. 2003; 42(3):113-20.

13. Bektaş İ, Yardimci F, Bektaş M, White Ka Psychometric Properties of the Turkish Version of Nursing Anxiety and Self Confidence with Clinical Decision Making Scale (NASC-CDM-T). Dokuz Eylül Üniversitesi Hemşirelik Fakültesi Elektronik Dergisi. 2017;10(2):83-92.

14. Lakdizgy S ،Mirsaedi GH ،Ghojanzadeh $M$ ، Zamanzadeh V. Nurses Participation in the Decisionmaking process. Nurs Midwife J. 2010; 5(17):19-25.

15. Rakhshani T, Motlagh Z, Beigi V, Rahimkhanli M, Rashki M. The relationship between emotional intelligence and job stress among nurses in Shiraz, Iran. The Malaysian journal of medical sciences: $\begin{array}{lll}\text { MJMS. } & 2018 ; & 25(6): 100\end{array}$ [DOI:10.21315/mjms2018.25.6.10] [PMID] [PMCID]

16. Karimi Naghandar M, Rahnemay Rahsepar F, GHolafroz M, Mohsenpor M. Comparison of ability of critical thinking and clinical decision making in nursing senior year students by nurses at the Hospital of the University of medical sciences, sabzevar, Iran. J Medical education. 2012; 12(12): 916-924. (In Persian)

17. Shahraki Moghadam A, Manzari T, Ghandehari Z. Nurses 'clinical care decisions decision special care hospital of Mashhad. J Sabzevar University of medical sciences. 2017; 2(24). (In Persian)

18. Arzani A, Lotfi M, Abedi A. Experiences of clinical decision making and operating room nurses, according to the causative theory banner. $\mathrm{J}$ Babol University of medical sciences. 2016; 18(4): 35-40. (In Persian)

19. Saeid Y, Javadi M, Mokhtari Nori J, Sirati M. On the relationship between emotional intelligence and demographic variables in nurses. J Military medicine. 2013; 15(1): 87-94. (In Persian)

20. Ghaderi M, Shamsi A.The relationship between emotional intelligence career with us in clinical nurses. J of nursing management. 2013; 2(3):8-15. (In Persian)

21. Heydari A, Kareshki H, Armat MR. Is nurses 'professional competence related to their personality and emotional intelligence? a cross-sectional study. Journal of Caring Sciences. 2016;5(2):121. [DOI:10.15171/jcs.2016.013] [PMID] [PMCID]

22. Farshi MR, Vahidi M, Jabraeili M. Relationship between emotional intelligence and clinical competencies of nursing students in Tabriz Nursing and Midwifery School. Research and Development in Medical Education. 2014; 4(1):91-5. [DOI:10.15171/rdme.2015.015]

23. Ibrahim H. A-F, Elgzar W. T. I, Mohamed R. E, \& Salem, G. M. M. Relationship between Nursing Students' Emotional Intelligence and their clinical performance during Obstetrics and Gynaecologic Nursing practical training. American Journal of Nursing Science. 2016; 5(6), 240-250. [DOI:10.11648/j.ajns.20160506.12]

24. Hadizadeh moghadam A, Tehrani M. Defining the relationship between emotional intelligence and style decision of Directors. Two journal of SHahed University. 2011; 18(2-47): 271-282. (In Persian)

25. Ghodosian B, Monfaredi raz B, Asgarzadeh H. The relationship between emotional intelligence and their managers make decisions in bojnord city high schools. J Quarterly educational. 2010; Article (6), 6(23): 1-18.

26. Jalili S, Pirayesh R, Ghasemzadeh L. The impact of emotional intelligence on the decisions of individual investors active in Tehran stock exchange. $J$ of accounting research. 2014; 4(3): 81-103. (In Persian)

27. Etebarian A, KHeyrmand M, Sadeghi A. The relationship between emotional intelligence and decision making styles for fitted plant managers made Isfahan. The journal of management development and transformation. 2014; 19:19-30.

28. Lak Dizaji S, Mirsaeidi G, Ghoujazadeh M, Zamanzadeh. Nurses participation in clinical decision-making process. Nursing and Midwifery Journal. 2010; 5(17):19-25. (In Persian)

29. Rasheed KP, Johnson B. Emotional Intelligence of Mental Health Nurses. Management Today. 2019;9(1):1-6. [DOI:10.11127/gmt.2019.03.01]

30. Khan S, Khan T, \& Ansari M. I. Assessment of Emotional Intelligence Among Staff Nurses of Tertiary Care Hospitals of Karachi, Pakistan. Journal of University Medical \& Dental College. 2018; 9(1): 20-25.

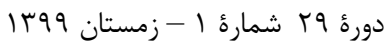

